\title{
White sand vegetation in an Amazonian lowland under the perspective of a young geological history
}

\author{
DILCE F. ROSSETTI ${ }^{1}$, GABRIEL M. MOULATLET ${ }^{2}$, HANNA TUOMISTO ${ }^{3}$, ROGÉRIO GRIBEL ${ }^{4}$, \\ PETER M. TOLEDO ${ }^{1}$, MÁRCIO M. VALERIANO ${ }^{1}$, KALLE RUOKOLAINEN ${ }^{5}$, MARCELO C.L. COHEN ${ }^{6}$, \\ CARLOS L.O. CORDEIRO ${ }^{1}$, CAMILO D. RENNÓ ${ }^{1}$, LUIZ S. COELHO ${ }^{4}$ and CARLOS A.C. FERREIRA ${ }^{4}$
}

\author{
${ }^{1}$ Instituto Brasileiro de Pesquisas Espaciais/INPE, Coordenação Geral de Observação da Terra/CGOBT, \\ Rua dos Astronautas, 1758, Jardim da Granja, 12245-970 São José dos Campos, SP, Brazil \\ ${ }^{2}$ Universidad Regional Amazónica/IKIAM, Km 7, Vía Muyuna, Parroquia Muyuna, Tena, Napo, Ecuador \\ ${ }^{3}$ University of Turku /UTU, Department of Biology, 20014, Turku, Finland \\ ${ }^{4}$ Instituto Nacional de Pesquisas da Amazônia/ INPA, Coordenação de Biodiversidade, \\ Av. André Araújo, 2936, 69067-375 Manaus, AM, Brazil \\ ${ }^{5}$ University of Turku/UTU, Department of Geography and Geology, 20014, Turku, Finland \\ ${ }^{6}$ Programa de Pós-Graduação em Geologia e Geoquímica, Universidade Federal do Pará/ \\ UFPA, Rua Augusto Correa 01, Guamá, 66075-110 Belém, PA, Brazil
}

Manuscript recevied on December 14, 2018; accepted for publication on March 22, 2019

How to cite: ROSSETTI DF ET AL. 2019. White sand vegetation in an Amazonian lowland under the perspective of a young geological history. An Acad Bras Cienc 91: e20181337. DOI 10.1590/0001-3765201920181337.

\begin{abstract}
What controls the formation of patchy substrates of white sand vegetation in the Amazonian lowlands is still unclear. This research integrated the geological history and plant inventories of a white sand vegetation patch confined to one large fan-shaped sandy substrate of northern Amazonia, which is related to a megafan environment. We examined floristic patterns to determine whether abundant species are more often generalists than the rarer one, by comparing the megafan environments and older basement rocks. We also investigated the pattern of species accumulation as a function of increasing sampling effort. All plant groups recorded a high proportion of generalist species on the megafan sediments compared to older basement rocks. The vegetation structure is controlled by topographic gradients resulting from the smooth slope of the megafan morphology and microreliefs imposed by various megafan subenvironments. Late Pleistocene-Holocene environmental disturbances caused by megafan sedimentary processes controlled the distribution of white sand vegetation over a large area of the Amazonian lowlands, and may have also been an important factor in species diversification during this period. The integration of geological and biological data may shed new light on the existence of many patches of white sand vegetation from the plains of northern Amazonia.
\end{abstract}

Key words: Amazonian wetlands, geological history, late Pleistocene-Holocene, megafan sedimentary dynamics, white sand vegetation.

Correspondence to: Dilce de Fátima Rossetti

E-mail: dilce.rossetti@inpe.br

ORCid: https://orcid.org/0000-0002-4574-1780 


\section{INTRODUCTION}

About $5 \%$ of the Amazonian rainforest biome has white sand vegetation (cf. Adeney et al. 2016). This fact has long attracted attention because of the unusual vegetation structure, and habitat endemism has been documented for both plants and animals (Fine et al. 2010, Matos et al. 2016, Ferreira et al. 2018). The white sand vegetation has species with more sclerophyllic leaves than those that grow in typical tropical forests, and the white sand forests have lower stature, slenderer trees, less stratification and simpler canopy structure compared to one typical of tropical forests. The white sand vegetation varies structurally from almost open vegetation to shrublands, woodlands or even dense forests with relatively low species diversity (Stropp et al. 2011, ter Steege et al. 2013). These formations were also locally refered as campinaranas (see Anderson 1981 for a review on this term), although the latter are found in a wider variety of substrates than sandy soils. Characteristics related to the sandy substrates of the white sand vegetation include extreme nutrient poverty, low water retention capacity and the presence of impermeable hardpan layers, which causes the soil hydrology to alternate between waterlogging and drought.

The reasons for the existence of open vegetation within the tropical forest matrix remain under debate, with main hypotheses related to the present-day climate (Franchito et al. 2012, Anadón et al. 2014) or the mid-Holocene climate (Pessenda et al. 2001), as well as hydrological gradients controlled by topography (ter Steege et al. 2006, Damasco et al. 2013), natural and anthropogenic fires (Hammond and ter Steege 1998, Flores et al. 2017), and edaphic constraints (ter Steege et al. 1993, Tuomisto et al. 2003, Vicentini 2004, Higgins et al. 2011). In particular, for the Negro-Branco basin, which contains large patches of white sand vegetation up to thousand square kilometers (ter Steege et al. 2000, Fine et al. 2010, Álvarez-Alonso et al. 2013, Adeney et al. 2016), one of the main hypotheses has been intense leaching of organic matter and clays during podzolization (Mendonça et al. 2014, Damasco et al. 2013). The white sand vegetation in this region has also been related to paleodunes formed by postulated drier climates in the Late Pleistocene-Holocene (Latrubesse and Nelson 2001, Carneiro-Filho et al. 2002, Zular et al. 2019) or depositional processes related to sedimentary dynamics, such as the reworking of fluvial bars (Latrubesse and Franzinelli 2005, Teeuw and Rhodes 2004).

It has been suggested that geological history, particularly during the Neogene-Quaternary period, affected environmental ggradients, therefore having a strong influence on Amazonian plant communities (Tuomisto and Ruokolainen 1997, Rossetti et al. 2005, Tuomisto 2007, Higgins et al. 2011, Misiewicz and Fine 2014, Pennington and Lavin 2016, Tuomisto et al. 2016, Cárdenas et al. 2017). A challenge to be pursued as to the origin of the substrate of white sand vegetation is to analyse the environmental information from a geological perspective. A previous publication (e.g., Adeney et al. 2016) described, in the Amazonian lowland, white sand vegetation developed on fluvial sedimentary deposits of early Miocene (Solimões Formation) or Plio-Pleistocene (Içá Formation) ages. However, a large proportion of this region (at least $700,000 \mathrm{~km}^{2}$ according to Rossetti et al. 2005 ) is covered by younger, i.e., Late Pleistocene and even Holocene deposits (Nogueira et al. 2013, Rossetti et al. 2014a, 2015, Cremon et al. 2016). Therefore, the influence of geological processes on the ecology and evolution of the white sand vegetation should be revisited, considering the high dynamism and young geological age of the substrate.

We postulate that recent sedimentary dynamics have caused substantial changes in the landscape of the Amazonian lowlands, thereby defining the characteristics of the substrates where the white 
sand vegetation is now found. We hope that the scrutiny of the main factor that favored the evolution of the white sand vegetation substrates, and the description of the plant communities associated with them, may elucidates the current geographical distribution of the white sand vegetation. This is a long-term task that will require much more work considering the various environmental and biological contexts of the Amazonian lowlands. Dry climate in the mid-Holocene (e.g., Pessenda et al. 2001) and Late Pleistocene-Holocene (Zular et al. 2019), as well as fire (e.g., Prance and Schubart 1978, Hammond and ter Steege 1998, Flores et al. 2017), have been most commonly cited. It is worth mentioning the changes in climate that occurred occurred during the last glaciation and following deglaciation stages. Although these factors may have caused a reduction in vegetation stature, they do not explain the origin of the white sand substrates. Numerous patches of white sand vegetation in this region are triangular-shaped paleolandforms related to residual megafans developed during the Late Pleistocene-Holocene (Rossetti et al. 2012a, b, 2014a, 2016). Megafans are formed by the rapid accumulation of large volumes of sand on relatively flat surfaces due to the existence of downstream bifurcating distributary river systems, as opposed to downstream convergent fluvial tributaries (e.g., Nichols and Fisher 2007). The establishment and development of white sand vegetation were due to the sum of various adjustments in the physical and chemical properties of the environments, as suggested by the patchy distribution (Adeney et al. 2016) and by the persistent confinement to megafan paleolandforms. Environmental changes were particularly shaped by the sedimentation and deactivation of megafans with a history that predates the modern landscape (e.g., Rossetti et al. 2012b, 2014b, 2016). Although conspicuous from a geological perspective, this information was not integrated with biological data when analysing the Amazonian white sand vegetation, perhaps due to the lack of explanation as to how the megafan dynamics influenced the plant distribution.

This work focuses on one of the large patches of white sand vegetation of the Negro-Branco basin (Fig. 1) to clarify how geologically recent paleoenvironmental changes caused by the evolution of megafans may have disturbed the lowlands of Amazonia, and acted as an agent of selective pressure on the species of white sand vegetation. We integrate published geological and botanical data with new floristic inventories of an easily accessible megafan of the Negro-Branco basin, known as the Viruá megafan (cf. Zani and Rossetti 2012, Rossetti et al. 2012a). For comparison, our analysis also includes adjacent areas of relatively recent (Late Pleistocene-Holocene) or significantly older (Plio-Pleistocene or older) geological history. An earlier publication has shown that the diversity of tree species in the patches of white sand vegetation from this megafan is lower than that in the surrounding rainforest (Cordeiro et al. 2016). We unify these data with additional tree plots to better detect floristic differences between forests on the megafan sediments and older basement rocks. Data from the understory vegetation were also included in our analysis to estimate how well the results for trees can be generalized to the rest of the flora. This type of multidisciplinary research is still challenging. The results presented herein should motivate the use of similar strategy in other Amazonian areas where megafans are present, to better understand their influence on the distribution of white sand vegetation within the rainforest matrix.

\section{PHYSIOGRAPHY AND GEOLOGY OF THE STUDY AREA}

The Viruá megafan is located in the northeast of the Pantanal Setentrional Basin, northern Brazil (Fig. 1a, b). This megafan (Fig. 1c-f), as well as the others over this region, is easy to identify in 

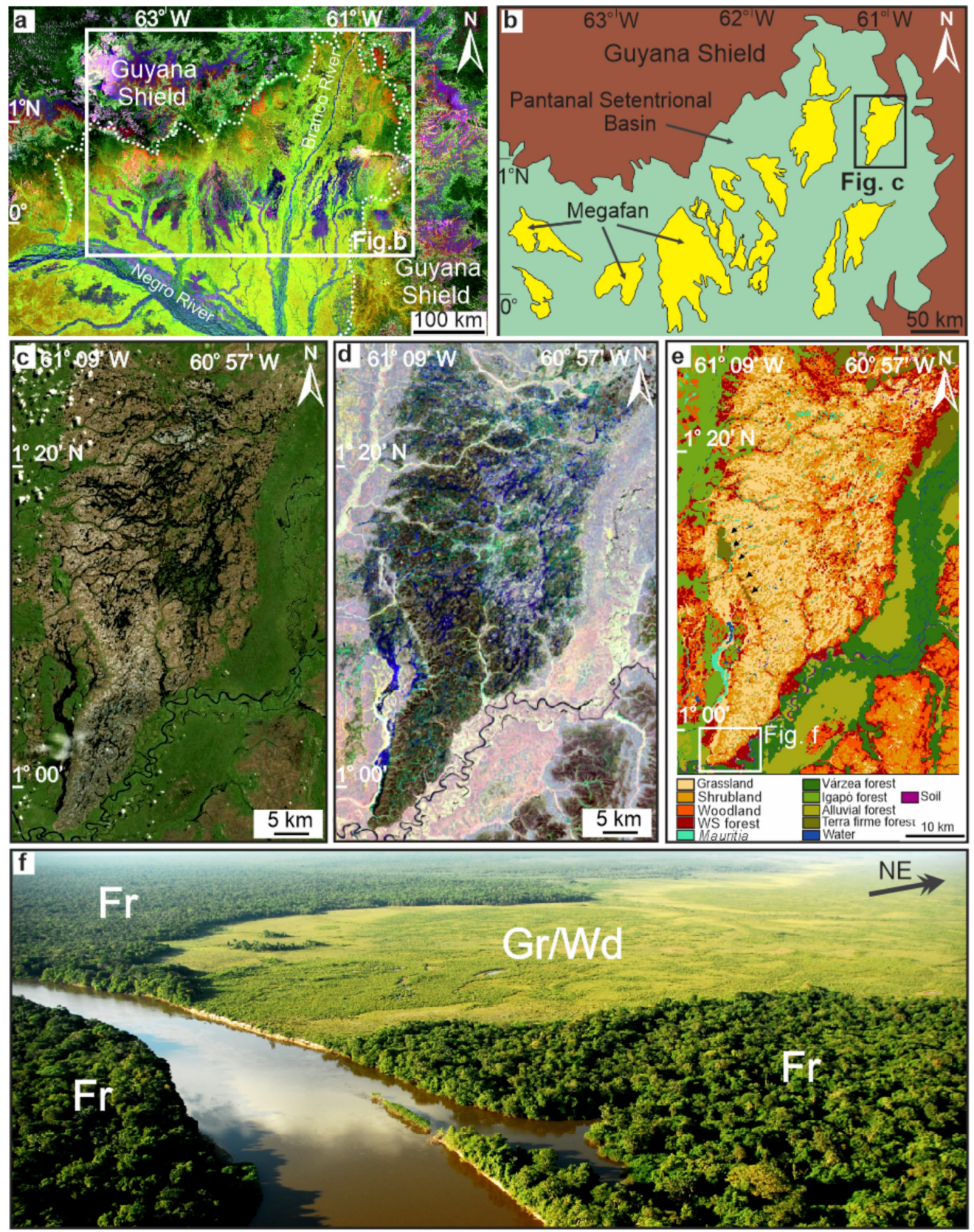

Figure 1- Megafan paleolandforms of the northern Amazonian wetlands and associated white sand vegetation. a) General view of several fan-shaped triangular megafan paleolandforms that characterize this region, inserted in the Pantanal Setentrional Basin (contoured by a dotted line). The image is a merger of Landsat and a digital elevation model of the Shuttle Radar Topography Mission- DEM/SRTM. b) Line drawing showing a detailed area of this basin where megafans (yellow colour) are abundant (see location in a). Landsat image of Google Earth ${ }^{\mathrm{TM}}$. c,d) Details of $\mathbf{b}$ showing the fan shape of the Viruá megafan in images of Google Earth ${ }^{\mathrm{TM}}$ (c) and Advanced Land Observing Satellite (ALOS)-Phased Array type L-band Synthetic Aperture Radar (PALSAR) (d). e) Vegetation map of the Viruá megafan paleolandform, which is highlighted by white sand vegetation ranging from grassland to forest (after Cordeiro et al. 2016) in sharp contrast to surrounding areas of rainforest. f) Aerial photograph of the southern end of a megafan (see location in figure e), illustrating its typical fan shape and vegetation cover consisting of grassland/ shrubland in sharp contrast to the rainforest (Fr). 
satellite images because its surface is covered by white sand vegetation in sharp contrast with surrounding areas of rainforest. The white sand vegetation varies from practically open grassland to open woodland, shrubland, and forest, the latter occurring in patches within the open vegetation (Fig. 1e, f). The northern sector of the Viruá megafan is consistently at a higher elevation than the southern fringes, but the slope is only $28 \mathrm{~cm}$ $\mathrm{km}^{-1}$ (Zani and Rossetti 2012). The low topographic gradient partialy explains why most of the megafan surface is submerged during the long wet season, which extends over nearly 8 months of the year, with precipitation peaks of $1800 \mathrm{~mm}$ from December to March. Water flow over the megafan surface forms drainage networks consisting mostly of narrow and shallow ephemeral channels with headwaters within the megafan (Fig. 2a, b, see also Rossetti et al. 2017a). Most rivers wane during the dry season. In addition to modern temporary streams, the megafan surface contains numerous paleochannels (Fig. 2c), some forming distributary networks. The residual channels and their associated deposits (i.e., sand bars, marginal levees and overbank sand sheets) produce numerous microtopographies over the megafan surface.

The fan shape of the Viruá megafan is typical of many classical megafan depositional systems (e.g., Hartley et al. 2010, Fielding et al. 2012). This morphology is inherent to the megafan sedimentary dynamics and is produced by the accumulation of large volumes of predomintantly sandy sediments on a wide flat terrain. The initially channelized sediment-loaded flows become unconfined and lose their ability to form numerous lobate-shaped sandy deposits. Consequently, the depositional lobes vary in space and time, and their amalgamation produces the fan-shaped megafan geometry (more details on megafan development can be found in Nichols and Fisher 2007).

At the surface, the Viruá megafan consists essentially of fine-grained quartz sands moderately to well-sorted, and these deposits also prevail in the shallow subsurface, with some local mud layers (Rossetti et al. 2012b). When the megafan deposition was initiated is unknown, but radiocarbon ages of mud layers interbedded in megafan sands indicate active deposition in the Late Pleistocene ( $\sim 37 \mathrm{ka} \mathrm{BP})$, with deactivation of sediments in the mid-Holocene (Rossetti et al. 2012b). Areas adjacent to the megafan are crystalline and metasedimentary Precambrian rocks of the Guiana Shield, as well as siliciclastic fluvial deposits (mainly sandstone and mudstone) older than the megafan sediments (i.e., mid-late Pleistocene, cf. Rossetti et al. 2015).

The geological history of the Viruá megafan is relatively well known (Rossetti et al. 2012a, b, 2014b, Zani and Rossetti 2012). Tectonic reactivation and climate with well defined dry and wet seasons led to the reorganization of drainage basins and megafan deposition (Rossetti et al. 2012b). The tectonic activity has disturbed the Viruá megafan surface even recently, i.e., approximately 2000 years ago (Rossetti et al. 2017a).

\section{MATERIALS AND METHODS}

The floristic tree inventory consisted of 20 plots: 11 plots in white sand forests inside the megafan and 9 plots in the rainforest outside the megafan (Fig. 3a). Plot locations were selected from accessible patches to cover a representative sector of these two environments. All plots outside the megafan were 1 ha in size, except for two 0.5 ha plots. At the megafan, the plot size ranged from 0.1 to 0.9 ha according to the size of the individual forest patch. Only the trees with crowns that had reached the forest canopy were sampled. Thus, trees with diameter at breast height $(\mathrm{DBH}) \geq 8$ $\mathrm{cm}$ were generally recorded in the plots with high rainforests outside the megafan. For the megafan area, the lowest DBH recorded was $6.4 \mathrm{~cm}$. The parabotanists helped identify the species in the 


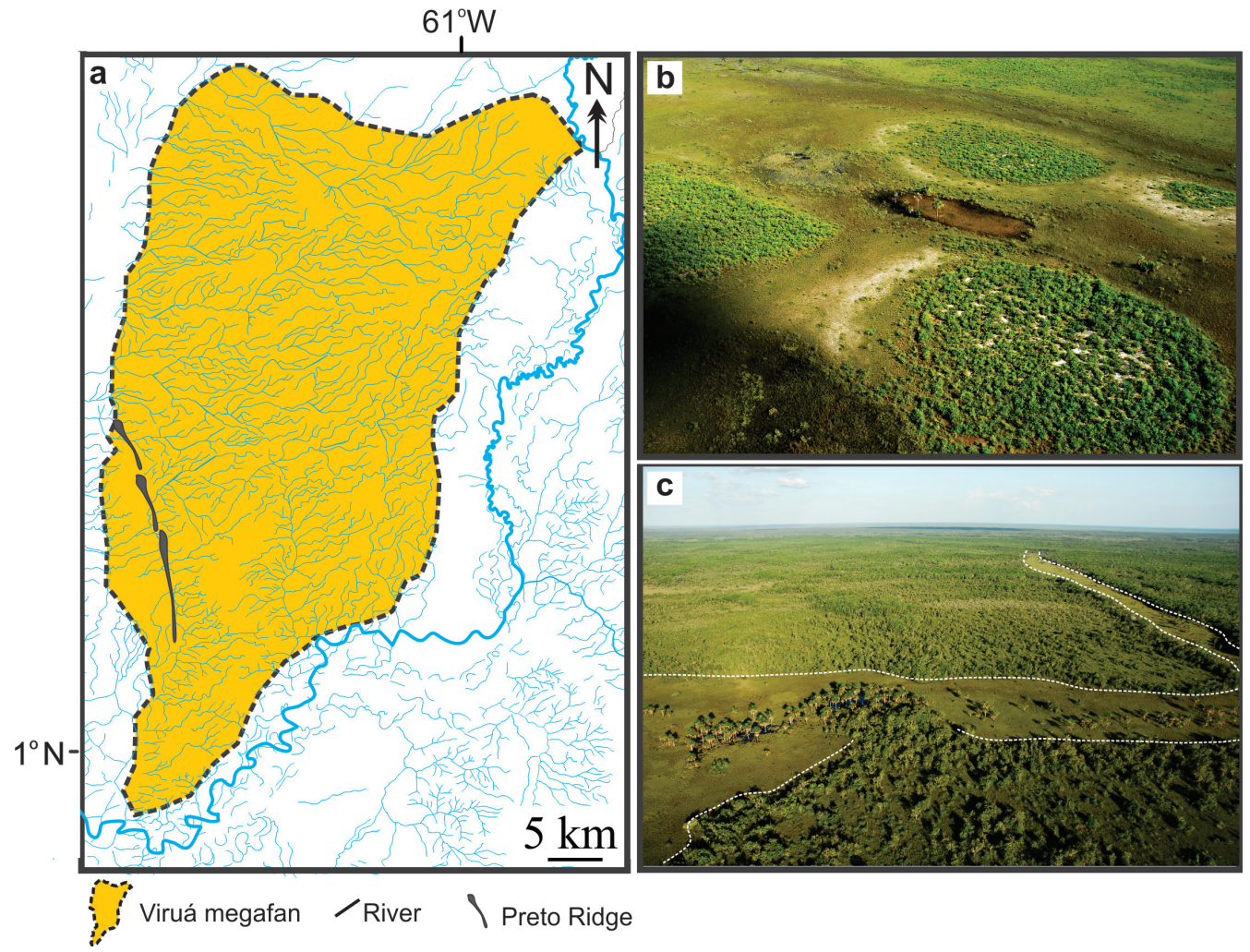

Figure 2 - a) Modern age drainage network on the Viruá megafan. b) Ephemeral channel. c) Paleochannel (dashed line).

field, but when the identification was not certain, a voucher was collected and later identified in the herbarium of the Instituto Nacional de Pesquisas da Amazônia (INPA).

Independent floristic data were collected for two groups of understory plants: pteridophytes and the family Melastomataceae. Earlier studies have shown that differences in species composition in these groups of plants covary with edaphic characteristics (Ruokolainen et al. 2007). To compare the understory composition of the white sand forests in the Viruá megafan with that of forests on other substrates, the pteridophyte and Melastomataceae communities were inventoried using 33 plots of $500 \mathrm{~m} \times 5 \mathrm{~m}$ (Fig. $3 \mathrm{~b}$ ). Fourteen plots were placed in forests on the sandy sediments of the megafan and 19 plots in forests on older substrates. Among the latter, 14 plots were located outside the megafan, whereas 5 plots were within the megafan limits, but located in outcrops of geologically older rocks projecting above the surface of megafan sediments. For pteridophytes, the inventory was limited to individuals with at least one leaf (for ferns) or leafy stem (for lycophytes) at least 10 $\mathrm{cm}$ long. Epiphytic and climbing individuals were included only if they had leaves less than $2 \mathrm{~m}$ above the ground level. Melastomataceae individuals that could be identified as belonging to this family were included, which in practice meant that they had at least one post-cotyledon leaf (and were taller than ca. $5 \mathrm{~cm}$ ). All individuals were recorded for a known species or for a field name, and for each, at least one representative voucher specimen was collected to verify the identification later. Duplicates of the specimens were deposited in the herbaria SP (São Paulo, Brazil) and TUR (Turku, Finland; herbarium acronyms according to Thiers, continuously updated). 


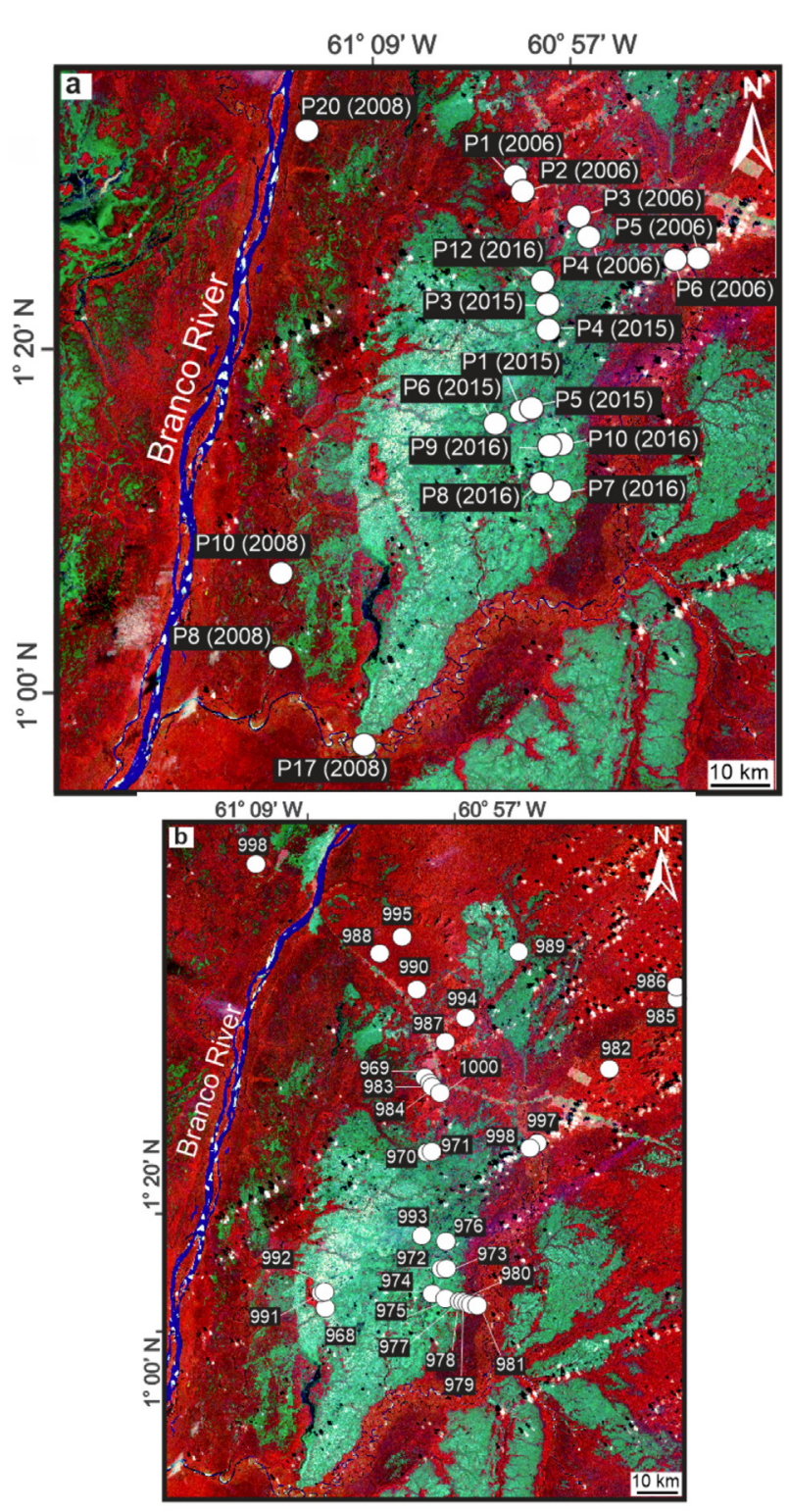

Figure 3 - Floristic inventory plots of trees (a) and pteridophytes and Melastomataceae (b) in the area of Viruá megafan. Background is an ASTER satellite image.

We examined each group of plants separately to determine whether abundant species are generalists (i.e., occurring both inside and outside the megafan) more often than the rarer species. Additionally, we investigated the species accumulation curves separately in each forest type as a function of the increased sampling effort. Species accumulation curves provide a relatively simple and easy to understand way to compare species richness among community samples of non-standard sample size (Soberón and Llorente 1993). To illustrate floristic patterns, we performed non-metric multidimensional scaling (NMDS) ordination and k-means clustering $(\mathrm{k}=2)$ of the plots using the one-complement of the Sørensen index as distance measure (Legendre and Legendre 1998).

\section{RESULTS}

A total of 8737 individuals of trees were recorded: 6639 (76\%) outside the megafan and 2098 (24\%) inside it (Table I). In total, 330 species were identified, of which 119 and 285 were recorded on the megafan sediments and older basement rocks, respectively. Among these, 211 species were exclusive to areas outside the megafan, while only 45 species were exclusive to megafan; $22.4 \%$ (i.e., 74) of the species were shared between these environments (Table II). The results of the NMDS ordering revealed a clearfloristic separation between the two analysed environments, and this division was recognized by the k-means classification (Fig. 4). The plots in the megafan sediments formed a denser cluster (albeit with an outlier) than the external plots. The latter were located in a more diverse geological context, covering Precambrian rocks, Pleistocene deposits older than the Viruá megafan and alluvial deposits of modern rivers. It is noteworthy that the P8-2016 was the most divergent tree plot. The results of rank abundance curves showed that in the current successional stage, the white sand substrate inside the megafan was dominated by generalist tree species also found outside this system. In addition, a few white sand specialists had intermediate abundance (Fig. 5a). Generalist species out of the megafan also tended to be more abundant than species confined only to these forests, but this pattern was not as clear as in forests of megafan sediments (Fig. 5d). When considering the sampling effort, it was observed 
TABLE I

Characteristics of the tree plots inventoried in the Viruá megafan area ( $N=$ number of individuals).

\begin{tabular}{|c|c|c|c|c|}
\hline Position & Plot & area (ha) & $\mathbf{N}$ & $\mathrm{DBH}(\mathrm{cm})$ range \\
\hline & P1 2006 & 1.00 & 516 & $9.6-94.3$ \\
\hline & P10 2008 & 0.50 & 908 & $3.2-50.3$ \\
\hline & P17 2008 & 1.00 & 446 & $9.6-71.0$ \\
\hline & P2 2006 & 1.00 & 647 & $8.3-159.2$ \\
\hline \multirow[t]{5}{*}{ outside megafan } & P20 2008 & 1.00 & 677 & $9.6-78.0$ \\
\hline & P5 2006 & 1.00 & 530 & $8.0-80.9$ \\
\hline & P3 2006 & 0.50 & 1177 & $3.2-69.6$ \\
\hline & P6 2006 & 1.00 & 613 & $6.7-133.8$ \\
\hline & P8 2008 & 1.00 & 1125 & $9.6-57.0$ \\
\hline \multirow[t]{6}{*}{ total (outside) } & & 8.00 & 6639 & \\
\hline & P1 2015 & 0.22 & 86 & $8.9-45.2$ \\
\hline & P10 2016 & 0.10 & 88 & $9.6-34.4$ \\
\hline & P12 2016 & 0.12 & 117 & $8.0-43.6$ \\
\hline & P3 2015 & 0.17 & 129 & $9.6-47.8$ \\
\hline & P4 2006 & 0.50 & 902 & $6.4-47.1$ \\
\hline \multirow[t]{6}{*}{ within megafan } & P4 2015 & 0.07 & 86 & $6.4-31.2$ \\
\hline & P5 2015 & 0.08 & 100 & $6.4-34.7$ \\
\hline & P6 2015 & 0.14 & 194 & $6.4-32.8$ \\
\hline & P7 2016 & 0.20 & 125 & $8.0-69-4$ \\
\hline & P8 2016 & 0.10 & 123 & $8.9-38.2$ \\
\hline & P9 2016 & 0.20 & 148 & $8.3-72.9$ \\
\hline total (inside) & & 1.91 & 2098 & \\
\hline total & & 9.91 & 8737 & \\
\hline
\end{tabular}

that the richness of tree species generally increased much more rapidly in the forest plots of the crystalline basement than in those plots of megafan (Fig. 6a), and the species turnover was lower in the latter. Tree forests on megafan sediments varied only slightly less in species richness than rainforest trees on the older basement (Fig. 6d).

For the understory vegetation, we recorded a total of 879 individuals of pteridophytes (65 morphospecies) and 665 individuals of melastomes (46 morphospecies). The megafan harboured ca. $14 \%$ of all individuals of pteridophytes and $37 \%$ of Melastomataceae (Tables III and IV). The NMDS ordination separated the white sand forest patches from the other forests in relation to pteridophytes (Fig. 4b) and Melastomataceae (Fig. 4c). This division was also present in the k-means classification, although some patches of white sand forest were mixed with the other forests. In both groups of understory plants, the most abundant species in the megafan were generalists growing also on other substrates as well (Fig. 5b, c). In 
TABLE II

Summary of data collected on eleven tree plots in the megafan sediment and nine tree plots in older basement rocks. Shared species are those found in both areas.

\begin{tabular}{|c|c|c|c|c|c|c|c|}
\hline & $\begin{array}{c}\text { Number of } \\
\text { species }\end{array}$ & $\begin{array}{l}\text { Number of } \\
\text { individuals }\end{array}$ & $\begin{array}{l}\text { Sampled } \\
\text { area (ha) }\end{array}$ & $\begin{array}{c}\text { Density of } \\
\text { Individuals/ha }\end{array}$ & $\begin{array}{c}\text { Density of } \\
\text { Individuals } \\
\text { with } \mathrm{DBH} \geq 10 \\
\mathrm{~cm} / \mathrm{ha}\end{array}$ & $\begin{array}{l}\mathrm{DBH} \\
\text { range } \\
(\mathrm{cm})\end{array}$ & $\begin{array}{c}\text { Number of } \\
\text { exclusive } \\
\text { species }\end{array}$ \\
\hline Total & 330 & 8737 & 9.9 & 882.5 & 659.2 & $3.2-159.2$ & - \\
\hline Megafan & $119(36.1 \%)$ & $2098(24.0 \%)$ & $1.9(19.2 \%)$ & 1104.2 & 737.9 & $6.4-72.9$ & $45(13.6 \%)$ \\
\hline Outside & $285(86.4 \%)$ & $6639(76.0 \%)$ & $8.0(80.8 \%)$ & 829.9 & 640.5 & $3.2-159.2$ & $211(63.9 \%)$ \\
\hline Shared & $74(22.4 \%)$ & - & - & - & - & - & - \\
\hline
\end{tabular}
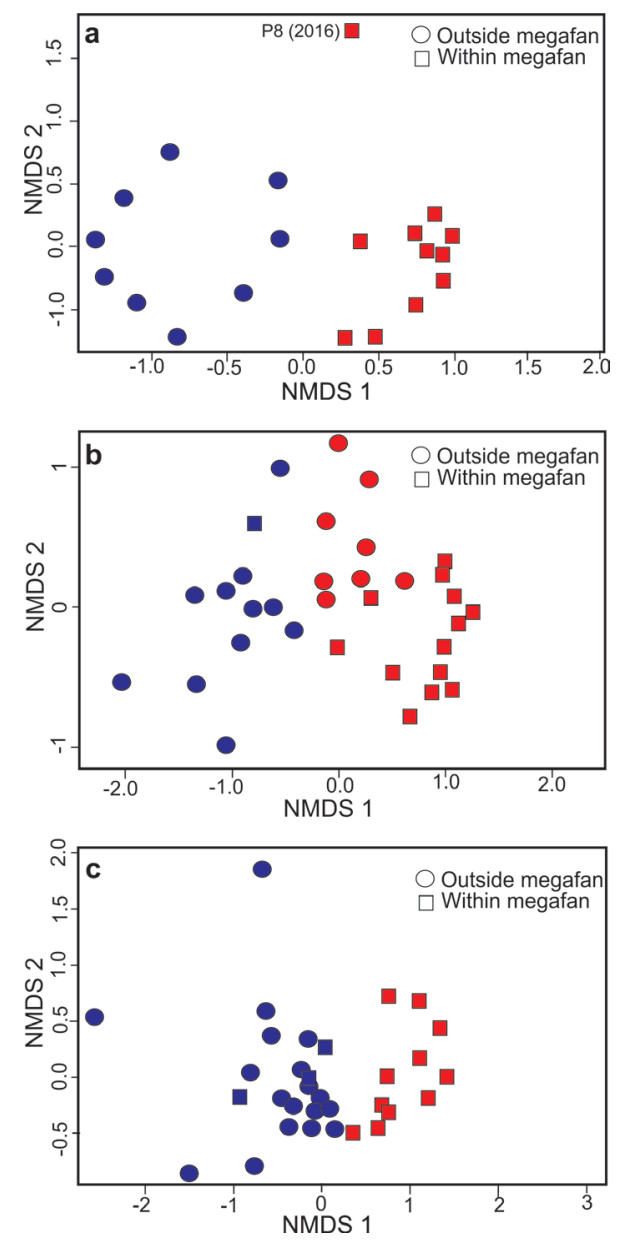

Figure 4 - Patterns of floristic similarity between plots in the area of the Viruá megafan, as visualized with NMDS ordination optimized for two dimensions. The plots are colored according to a non hierarchical k-means cluster classification using 2 clusters (blue $=$ cluster 1 ; red=cluster 2 ). Symbols indicate whether each plot is in megafan sediments or older basement rocks. The plots close together share a larger proportion of species, calculated by Bray-Curtis distances, than the plots that are more separated. a) Trees. b) Pteridophytes. c) Melastomataceae. forests growing on a substrate other than megafan sediments, the dominance of generalist species was especially evident among Melastomataceae (Fig. 5e, f). The plots on megafan sediments varied less in the richness of pteridophyte species than in the plots on older rocks of the basement (Fig. $6 \mathrm{~b}$ ), and the species turnover was also higher in the latter than in the megafan (Fig. 6e). For Melastomataceae, in contrast, both forest types had approximately the same species richness per plot (Fig. 6c), and species turnover appeared slightly higher on megafan sediments than on older rocks of the basement (Fig. 6f).

\section{DISCUSSION}

\section{WHITE SAND VEGETATION STRUCTURE AS A FUNCTION OF SEDIMENTARY DYNAMICS IN THE VIRUÁ MEGAFAN}

According to our data, a relatively small proportion of the plant species in the forests of megafan sediments is specifically adapted to white sands. García-Villacorta et al. (2016) showed that a fairly large proportion $(77 \%)$ of tree species growing in white sand forests is also found in other forest habitats, and Vicentini et al. (2016) reported that the white sand vegetation is species-poor when compared to adjacent environments, where edaphic conditions prevail. The finding that dominant tree and understory species in white sand plots are also found in terra firme forests is consistent with the data presented by García-Villacorta et al. (2016). 
TABLE III

Overview of the data and number of morphospecies of pteridophytes and Melastomataceae found in each plot. The location in megafan sediments and basement rocks (Ouside) is indicated for all plots.

\begin{tabular}{|c|c|c|c|}
\hline Plot & Local & $\begin{array}{c}\text { Number of } \\
\text { Melastomataceae } \\
\text { morphospecies }\end{array}$ & $\begin{array}{c}\text { Number of } \\
\text { Pteridophytes } \\
\text { morphospecies }\end{array}$ \\
\hline 968 & Outside & 8 & 13 \\
\hline 969 & Outside & 10 & 17 \\
\hline 970 & Megafan & 8 & 5 \\
\hline 971 & Megafan & 8 & 3 \\
\hline 972 & Megafan & 11 & 3 \\
\hline 973 & Megafan & 6 & 3 \\
\hline 974 & Megafan & 5 & 4 \\
\hline 975 & Megafan & 9 & 2 \\
\hline 976 & Megafan & 8 & 6 \\
\hline 977 & Megafan & 15 & 5 \\
\hline 978 & Megafan & 9 & 3 \\
\hline 979 & Megafan & 7 & 3 \\
\hline 980 & Megafan & 9 & 6 \\
\hline 981 & Megafan & 16 & 5 \\
\hline 982 & Outside & 1 & 8 \\
\hline 983 & Outside & 12 & 4 \\
\hline 984 & Outside & 11 & 9 \\
\hline 985 & Outside & 0 & 12 \\
\hline 986 & Outside & 2 & 11 \\
\hline 987 & Outside & 7 & 8 \\
\hline 988 & Outside & 9 & 5 \\
\hline 989 & Outside & 9 & 6 \\
\hline 990 & Outside & 7 & 2 \\
\hline 991 & Outside & 11 & 2 \\
\hline 992 & Megafan & 12 & 8 \\
\hline 993 & Megafan & 8 & 5 \\
\hline 994 & Outside & 7 & 20 \\
\hline 995 & Outside & 10 & 4 \\
\hline 996 & Outside & 12 & 17 \\
\hline 997 & Outside & 3 & 1 \\
\hline 998 & Outside & 10 & 3 \\
\hline 999 & Outside & 12 & 4 \\
\hline 1000 & Outside & 9 & 7 \\
\hline
\end{tabular}

In addition, white sand vegetation is poor in species when compared to adjacent environments where edaphic conditions prevail (Vicentini et al. 2016). Although white sand vegetation may indeed be considered distinct from other types of vegetation, it can also be considered as part of a continuum along several environmental gradients. We provide a discussion focusing on the patchy distribution and isolation of white sand substrates in the rainforest matrix and explain their relationship to megafan deposits

We found that the locally dominant species in the white sand vegetation occur in habitats without white sand substrates more frequently than nondominant plant species. This pattern is compatible with the idea that, floristically, the white sand vegetation of the Viruá megafan represents a stage in which relatively few specialists in white sand forest managed to reach the area. Several explanations can be drawn to explain this trend, one being locally high abundance leading to increased seed production, thus enhancing the likelihood of establishment even in marginal habitats (Pulliam 1988). Although the relationship between abundance and environmental niche breadth can not be resolved with the data currently available to us, it is possible that the competitive capacity expressed by high abundance may also be linked to habitat generalists.

The substrate of the white sand vegetation, composed mainly of quartz grains, may have increased the acidity of the groundwater due to the flow of alkaline waters outside the system as surface runoff. The lack of weathering of primary minerals, forest nutrition and $\mathrm{CO}_{2}$ released by the roots may cause changes in the groundwater pH (Grimaldi and Pedro 1996). Thus, subsequent acid hydrolysis could have further contributed to the establishment of species adapted to highly acidic conditions. As a result, some species of white sand vegetation adapted physiologically to tolerate this set of environmental stress may 


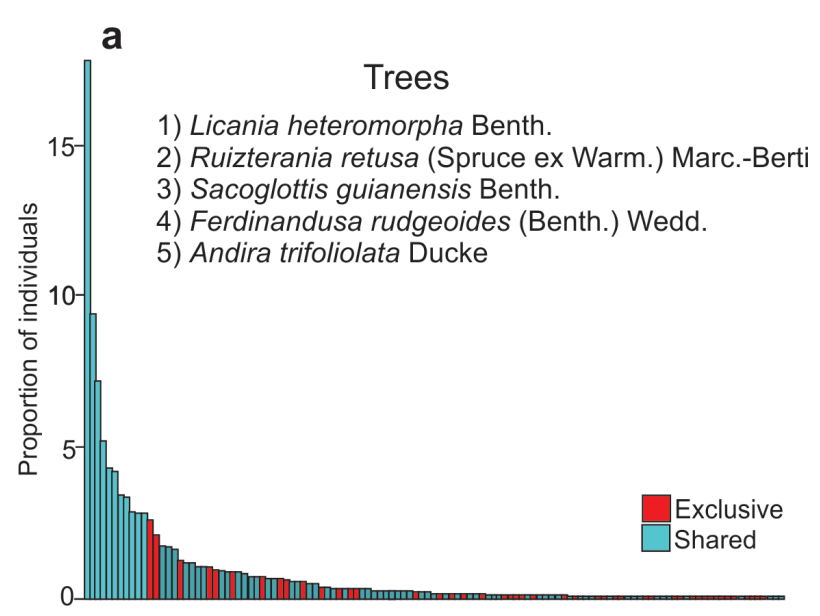

b

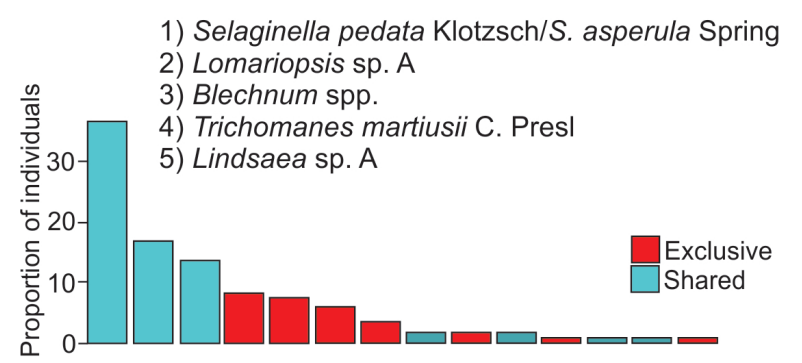

C Melastomataceae

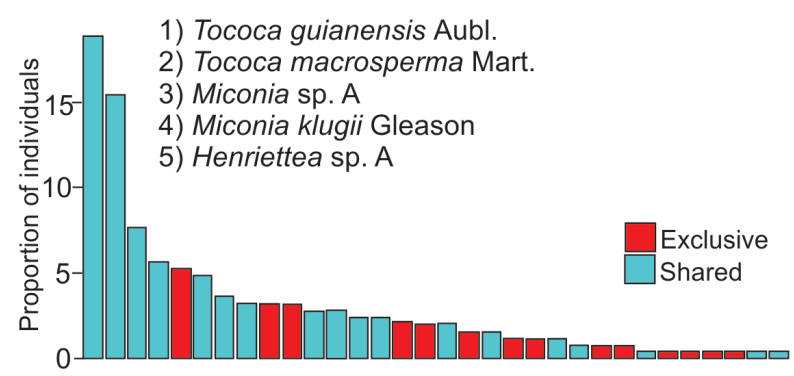

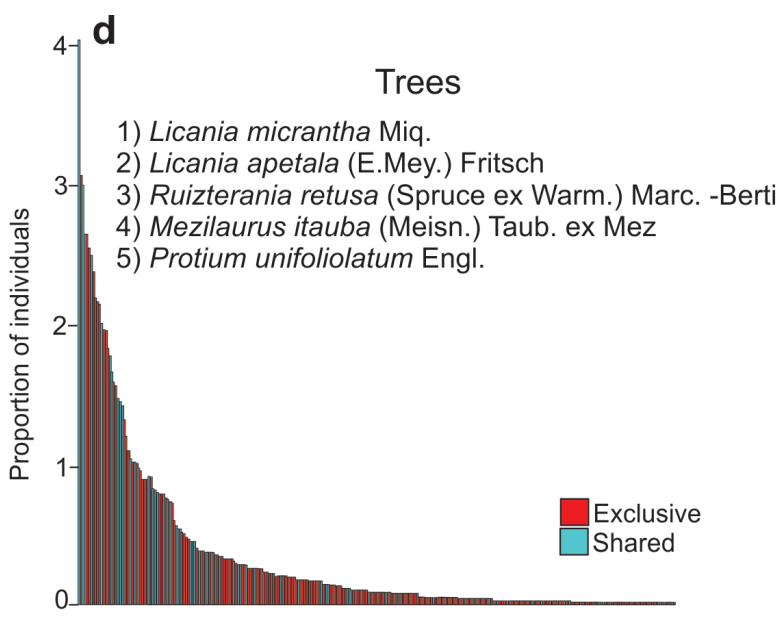

e Pteridophytes
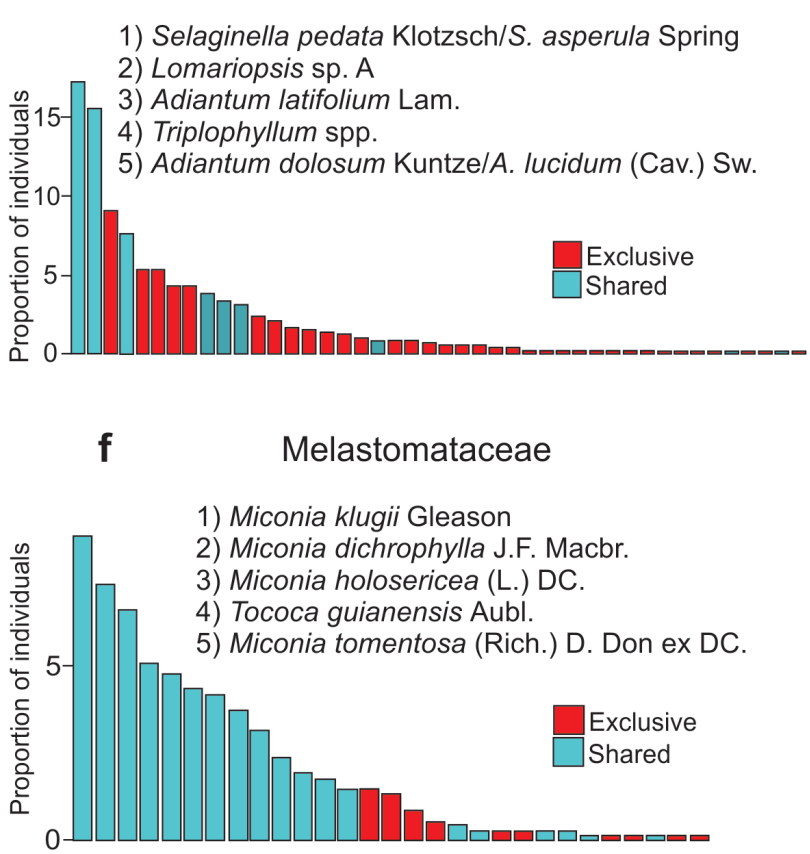

Figure 5 - Rank abundance curves of plant species inventoried in the area of Viruá megafan. a-c) Plots in megafan sediments. d-f) Plots in basement rocks. Species colored in red occur exclusively in megafan sediments or other substrates, while species colored in blue are shared by at least one plot located in each environment. The names of the species are given for the five most abundant species in each group of plants. (see the colored figure in the online version for color reference.

have persisted, whereas rainforest species were retained in more suitable habitats around. The lack of competition with rainforest species may have caused the spread of white sand vegetation over the megafan. In addition, previous works have related the contrasting vegetation along the Viruá megafan to changes in soil texture and fertility (Damasco et al. 2013) or variations in the soil organic matter controlled by podzolization (Mendonça et al. 2014).

On the other hand, contrasting water availability during alternations between dry and wet seasons currently determine which species are able to persist in a given microsite. It is likely that this seasonal pattern was intensified in the geological 

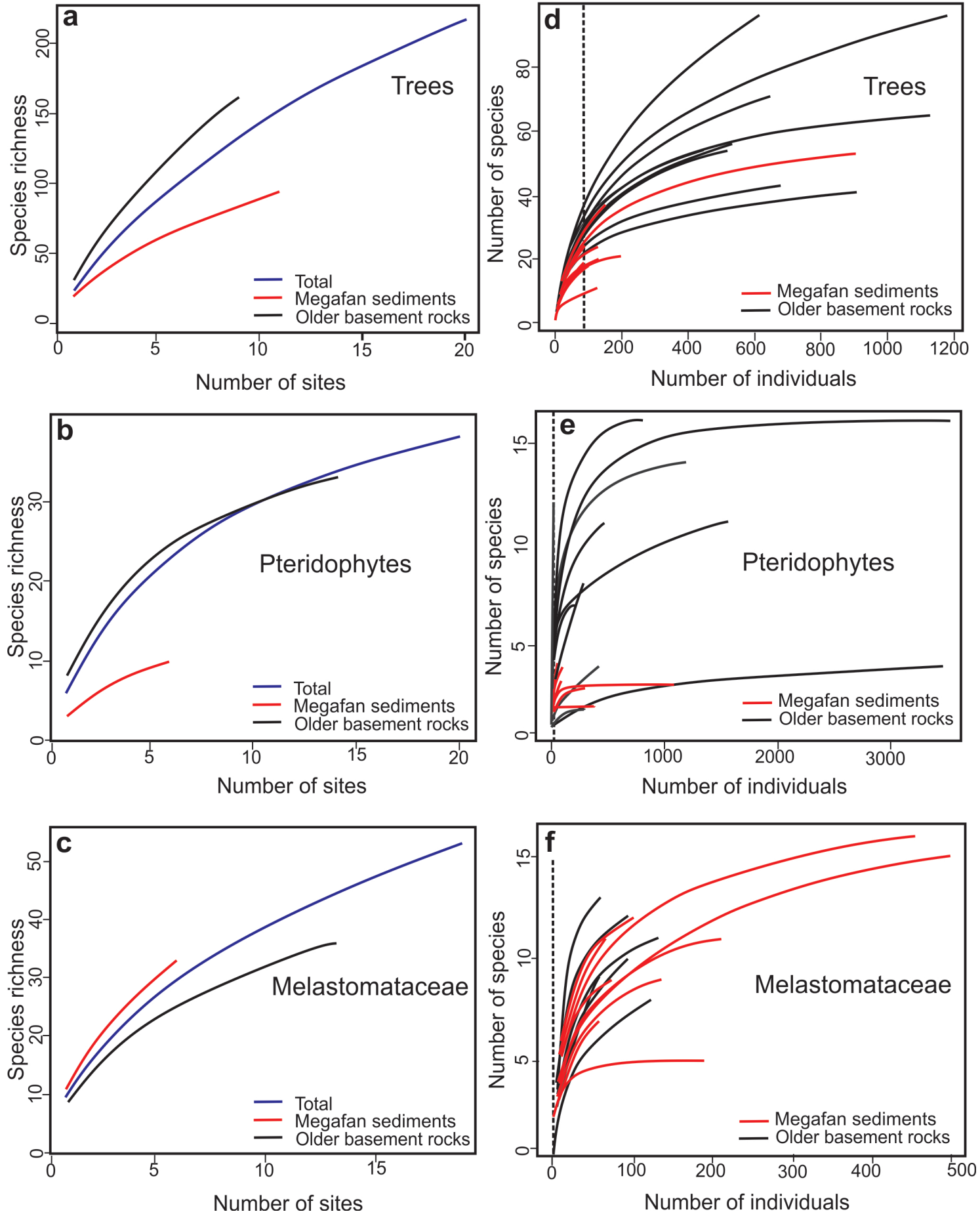

Figure 6 - Curves of accumulation and rarefaction of species for the plots inventoried in the Viruá megafan. a-c) Curves of accumulation of species with the inventoried sites added to the sample in a random order, after having reduced the number of individuals in any plot. Separate species accumulations curves were traced for each kind of environment and for both combined. d-f) Rarefaction curves with the number of expected species showed for different numbers of individuals sampled. Each line represents one plot and the gray levels (or colors in the online version) indicate whether the plot was located in megafan sediments or basement rocks. The vertical dashed line indicates the smallest number of individuals in any plot (86 for trees; 13 for pteridophytes; 1 for Melastomataceae). 
TABLE IV

Summary of data for pteridophytes and Melastomataceae collected in 33 plots in the study area. The plots were classified according to their occurrence in the megafan sediments and in the basement rocks.

\begin{tabular}{ccccc}
\hline & Number of species & Number of individuals & Exclusive species & Sampled area (ha) \\
\hline Pteridophytes & \multicolumn{3}{c}{} & \\
\hline Total & 65 & 879 & NA & 8.25 \\
Megafan & $26(40)$ & $119(13.54)$ & 14 & 3.5 \\
Outside & $51(78.46)$ & $760(86.46)$ & 39 & 4.75 \\
Shared species & $12(18.46)$ & NA & NA & NA \\
\hline Melastomastaceae & & 665 & NA & 8 \\
\hline Total & 46 & $246(36.99)$ & 15 & 3.5 \\
Megafan & 36 & $419(63.01)$ & 10 & 4.5 \\
Outside & 31 & NA & NA & NA \\
Shared species & $21(46.65)$ & &
\end{tabular}

past, considering the mansoonal climate regime proposed during the megafan evolution (Rossetti et al. 2012a). An earlier publication suggested a less dense canopy in terra firme forests during colder episodes of the Last Glaciation Maximum in northern Amazonia (Häggi et al. 2017). Therefore, this ecosystem is probably more permeable to white sand vegetation and organisms with dispersal capacities.

Recent publications have also suggested that topographic contrasts resulting from sedimentary dynamics, linked or not to neotectonic reactivations, are a central factor in regulating hydrology over the Viruá megafan (Rossetti et al. 2017b, 2018). Megafans were only recently recognized in Amazonia, and a model was presented to explain their formation under the influence of neotectonics (see Rossetti 2014 review, and several references in it), including in the Viruá area (e.g., Rossetti et al., 2017a). In particular, the model presented by Rossetti et al. (2012a, b, 2014b), Zani and Rossetti (2012) explained the formation of the Viruá megafan due to the combination of neotectonics and monsoon climate.

As expected, the deposition of large volumes of sands during the formation of the Viruá megafan impacted the pre-existing vegetation (Fig. 7a), whereas areas of rainforest outside this depositional environment remained relatively unchanged (except the plot P3-2006, which had a community of anomalous trees for a plot outside the megafan due to its location on a sandy terrain at the megafan edge). First, tectonic reactivation would have subsidized the area (Fig. 7b), thus increasing the space for the renewal of sediment deposition (Fig. $7 \mathrm{c}, \mathrm{d}$ ). As a consequence, large areas of terra firme forest, presumably similar to that found outside the megafan, were probably disturbed by sudden flooding. The topographic gradient produced by tectonics also had a great impact on drainage networks, as evidenced by the replacement of tributary rivers by distributary rivers, the latter being attested by the megafan paleolandform (cf. Rossetti et al. 2012b). As the megafan evolved, vegetation growth was prevented in areas of active sediment deposition and/or frequent flooding. However, the deactivation of significant depositional sites in the mid-Holocene (Fig. 7e) expanded the deposits exposed to pedogenesis and plant colonization. The external inflows were cut off due to the tectonic capture of the main feeding drainage (cf. Rossetti et al. 2012a), a process that caused the megafan to be drained only by internal streams fed by precipitation during rainy seasons 

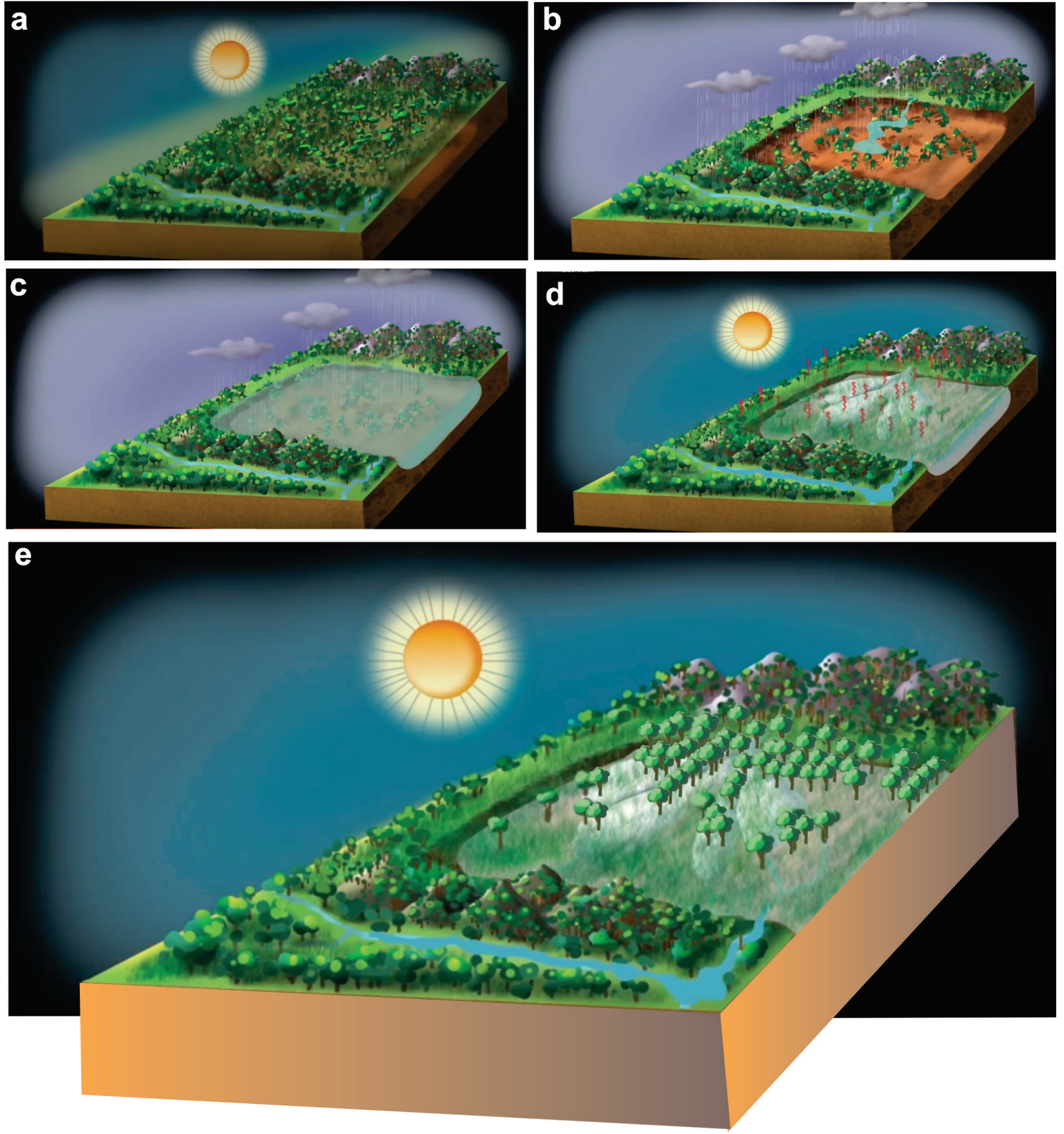

Figure 7 - Schematic model that illustrates how the sedimentary dynamics related to the Amazonian megafans may have proceeded to create suitable terrains for the development of the patches of white sand vegetation in a rainforest matrix. a) Amazonian region covered by typical rainforest. b) Tectonically-triggered instability leading to mild subsidence. c) The subsiding terrain was more suitable to flooding, creating wetlands during wet seasons. d) The wetlands were filled with sediments sourced from the erosion of the highland rocks of the Guyana Shield, forming the sandy-dominated megafans. e) After abandonment only a few thousand years ago, the nutrient-poor sandy megafan deposits constituted favorable sites for colonization by white sand vegetation. Grasslands/ shrublands occupy topographically lower-lying terrains, most influenced by seasonal flooding, whereas physiologically adapted white sand trees colonize areas that remain topographically higher (see text for further explanation). 
(Fig. 4a). The lack of perennial flow resulted in the variation of the distribution of flooded and nonflooded areas according to topographic gradients, which were controlled by both the general lowlying dipping slope of the megafan morphology and by the microreliefs imposed by the various megafan subenvironments (Rossetti et al. 2012a, Cordeiro et al. 2016).

The vegetation structure of the plot P82016 also appears to have been determined by topographic gradients resulting from the recent tectonic reactivation. This site is located in a megafan area that has been recently subsidized (only $\sim 2$ ka ago) by tectonic reactivation (Rossetti et al. 2017a). According to these authors, evidence of tectonics in this area includes: i) the prevalence of anomalous drainage patterns, such as subdentritic and trellis; ii) orthogonal channel junctions; and iii) straight morphostructural lineaments in channels and lake margins aligned in NW-SE and NESW directions, i.e., paralleling main regional structural trends. Tectonics would have formed a small catchment basin of local streams within the megafan, which favored the establishment of tree species physiologically more tolerant to floods than elsewhere in the megafan plain.

The effect of environmental changes produced by sedimentary dynamics on the distribution of plant communities was recorded in other megafan depositional systems in the world. For example, the distribution of plant species in the Okavango South African megafan (e.g., Stanistreet and McCarthy 1993, Gumbricht et al. 2001), the most classic example of megafans on Earth, is controlled by the sedimentary dynamics of channel systems through complex feedback mechanisms relating hydrology, sediment deposition, nutrient availabity, soil properties and flood regime (e.g., Ellery et al. 2003). In the case of the Viruá megafan, the complex hydrological context appears as an important control on the establishment and evolution of the associated white sand vegetation, since tree growth is generally prevented by high water table. Consequently, herbs and shrubs occupy areas with higher water table compared to trees, which colonized areas that were unflooded or that remained longer above the level of yearly floods. Trees are more frequent in topographically elevated areas closer to sediment sources (megafan apice), where the rate of sediment accumulation is higher than less elevated, marginal areas, which are sediment-starved and longer flooded throughout the year. Channel bars, marginal levees and sand dunes are also sites with higher sediment accumulation, which results in local reliefs favorable to the colonization of trees.

\section{WHITE SAND VEGETATION OF OTHER AMAZONIAN MEGAFANS}

A model relating the establishment and evolution of white sand vegetation to the sum of several environmental variables triggered by sedimentary dynamics in the Viruá megafan may also be applied to explain the patches of white sand vegetation confined to other megafan landforms of the NegroBranco basin. This region is part of the Pantanal Setentrional Basin, which corresponds to a tectonic area that subsidized in the late Quaternary (Rossetti et al. 2016). High volumes of sediments, mostly sands, derived from the erosion of granitic and quartzitic rocks along this plateau were transported by increased water discharge during rainy seasons. Tectonics also favored subsidence in adjacent areas, where space was created to accommodate the megafan sediments. The periods of high and low rainfall prevented the accumulation of water throughout the year and ensured that the area remained with shallow wetlands, suitable for the development of megafans.

Similar to the Viruá megafan, all megafans of the Pantanal Setentrional are covered by white sand vegetation. As the white sands of these megafans provide substrates that are much different for plants than those that prevail in the 
most common types of soil in Amazonia, they have a significant impact on the distribution of plant species. In particular, distribution patterns are generally affected for those species that are most specialized or even endemic to white sands (ter Steege et al. 2000, Fine and Baraloto 2016, Guevara et al. 2016). In the Pantanal Setentrional, the sandy substrate reflects the depositional characteristics of themegafan, differing from other areas where it can be a product of intense leaching of organic matter and clays during podsolization (Damasco et al. 2013, Mendonça et al. 2014). However, once established, the white sand vegetation created an environment that, together with the other control factors discussed in the previous section, may have facilitated the arrival of generalist species of rainforest.

\section{A YOUNG GEOLOGICAL HISTORY INFLUENCING SPECIES DIVERSITY}

Several previous studies have suggested that geographic variation in species composition in Amazonia is largely due to the variation in geologically induced edaphic characteristics (e.g., Higgins et al. 2011, Misiewicz and Fine 2014, Cárdenas et al. 2017). However, these authors have often considered Plio-Pleistocene or even older habitat changes, whereas many modern plant clades may have originated more recently (Fine et al. 2014). The importance of considering recent speciation of plants was also pointed out by Pennington and Lavin (2016), who recommended additional efforts to characterize the most common Amazonian species and to detect incipient and possibly non-monophyletic speciation processes in this region.

The first lineages of Protium and Tetragastris (Burseraceae) adapted to white sand soils appeared at the end of the Miocene and Pliocene (Fine et al. 2014), a period of hydrological instability due to the Andean uplifting (e.g., Hoorn et al. 1995). However, taxonomic and phylogenetic analyses of white sand forests have recorded recent divergence and neo-endemism on a regional scale (Guevara et al. 2016).

Our sampling design does not allow us to determine when the species of white sand vegetation first arrived or when divergence occurred. The hypothesis proposed is that the relatively recent megafan dynamics may have been the engine for triggering several interrelated changes in the environment, including gradients in soil properties and hydrology, which worked together to define the characteristics of the substrates favorable to the establishment and development of white sand vegetation. It is plausible to invoke this hypothesis also to explain recent speciation events, because as white sand species become biologically adapted to new niches, they may experience additional divergence and speciation (Frasier et al. 2008, Fine and Kembel 2011).

The last geological events that shaped the Amazonian landscape are relevant to discuss the most recent processes of speciation and population divergence also of animal species. Although time and species diversification processes in general are controversial issues that will not be resolved soon (e.g., Arita and Vásquez-Dominguez 2008, Rull 2008, Dick et al. 2013, Koenen et al. 2015), phylogenetic studies in Amazonia increasingly support a late Pleistocene age for several clades of modern animals (e.g., Ribas et al. 2009, 2012, Souza-Neves et al. 2013, Fernandes et al. 2014, Garzon-Orduna et al. 2014, Boubli et al. 2015). In addition, environmental changes over the geological time have been frequently claimed to explain many events of species divergence (e.g., Naka et al. 2007, Borges and Silva 2012, Ribas et al. 2012, Boubli et al. 2015). Questions remain about the identification of habitat-related parameters with greater impact on genetic diversity and population divergence across the Amazonian landscape. A bird-focused study recently advanced this issue by introducing a model of a young Amazonian biotic 
divergence (Ribas et al. 2012). Following the most commonly accepted hypothesis of river barriers for species dispersion (e.g., Ribas et al. 2009, Souza-Neves et al. 2013, Fernandes et al. 2014, Boubli et al. 2015), those authors arguably related the recent bird diversification to the formation of main Amazon tributaries, such as the rivers Madeira, Negro, Tapajós, Xingu and Tocantins, presumably of Pleistocene age. However, there are also studies (e.g., Naka et al. 2012, Harvey et al. 2017) arguing that the separation of many bird populations across the Amazonian landscape was due to other environmental changes than river barriers. Genomic markers have been used to relate species diversity and population divergence in Amazonian to variations in the distribution of floodplain and terrestrial environments during the Quaternary due to other environmental processes, mainly seasonal flooding, river capture and/or sealevel rise associated with climatic changes (Harvey et al. 2017).

In addition to these hypotheses, we argue that the relatively recent high sedimentary dynamics, associated with the evolution of megafan depositional systems over an extensive area of the Negro-Branco River basin, may have been an important component of ecological traits to promote divergence. The evolution of megafans over this region has drastically disrupted the river patterns from tributaries to distributaries, naturally increasing the frequency of changes in river courses and river captures. As a consequence, the distribution of floodplains and terrestrial environments were also strongly modified, along with the lithological, topographical, hydrological and edaphic characteristics. The interaction of these complex habitat-related processes promoted by sedimentary dynamics during the Late Pleistocene and Holocene in northern Amazonia should be better examined to facilitate discussions on species diversity and divergence. In addition, increasing studies on the timing of these events by expanding
DNA sequencing to different organisms may help determine the environmental changes of greatest influence on genetic and phenotypic variations.

\section{CONCLUSION}

The relatively recent (i.e., Late PleistoceneHolocene) geological formation of megafans may be a major factor to explain the patches of white sand vegetation in the Negro-Branco river basin. The linking of biological processes with recent geological forces has the potential to provide a more comprehensive understanding of the functioning of the present-day Amazonian ecosystem, especially when combined with phylogenetic analyses and population genetics. Molecular, ecophysiological and taxonomic studies are needed to measure the degree of divergence of species in the megafan sediments and in the basement rocks, since recent divergences are difficult to detect.

\section{ACKNOWLEDGMENTS}

The authors thank the Fundação de Amparo à Pesquisa do Estado de São Paulo (FAPESP, Project \#13/50475-5 to DFR) and the Academy of Finland (AKA grant to HT) for the support to this research. The Conselho Nacional de Desenvolvimento Científico e Tecnológico (CNPq) is also recognized for providing research grants for DFR, MCLC, MMV and RG. GMM was supported by the University of Turku Graduate School. Logistical support during fieldwork was provided by the Serviço Geológico do Brasil_(CPRM) of the State of Roraima and the Instituto Chico Mendes de Conservação da Biodiversidade (ICM-Bio). The authors are grateful to the parabotanists Paulo Assunção and José Ferreira Ramos for their help in identifying tree species, as well as an anonymous reviewer who helped significantly improve the initial version of this article.

\section{AUTHOR CONTRIBUTIONS}

DILCE F. ROSSETTI was the leader of the article, and also responsible for the acquisition 
and analysis of geological data. She was also in charge of promoting the multidisciplinary discussion that resulted in the model to explain the occurrence of white-sand vegetation in the Viruá megafan. GABRIEL M. MOULATLET integrated the field group responsible for the aquisition of botanical data including the species of understory vegetation. HANNA TUOMISTO was the leader of the group focused on species of understory vegetation, contributing with the aquisition and analysis of field data concerning to this subject. ROGÉRIO GRIBEL was the leader of the group focused on forest vegetation, contributing with the aquisition, processing and analysis of tree species. PETER M. TOLEDO contributed with the discussion focused on biodiversity patterns. MÁRCIO M. VALERIANO gave important contributions in the processing of remote sensing data. KALLE RUOKOLAINEN integrated the field group responsible for the aquisition of data on the species of understory vegetation. He also provided important contribution to analyse these data and integrate them with geology. MARCELO C.L. COHEN contributed with the geological characterization of the Viruá megafan, having actively worked during several field campaigns aiming the acquisition of numerous cores that served as the basis for the geological interpretation used in this article. CARLOS L.O. CORDEIRO assisted the field campaings, having contributed with the aquisition of botanical data focused on tree species. CAMILO D. RENNÓ helped the analysis of remote sensing data. LUIZ S. COELHO and CARLOS A.C. FERREIRA helped the aquisition of floristic inventories of trees, contributing to the identification of species.

\section{REFERENCES}

ADENEY JM, CHRISTENSEN NL, VICENTINI A AND COHN-HAFT M. 2016. White-sand ecosystems in Amazonia. Biotropica 48: 7-23.

ÁLVAREZ-ALONSO J, METZ MR AND FINE PVA. 2013. Habitat specialization by birds in Western Amazonian white-sand forests. Biotropica 45: 365-372.
ANADÓN JD, SALA OE AND MAESTRE FT. 2014. Climate change will increase savanas at the expense of forests and reeless vegetation in tropical and subtropical Americas. J Ecol 102: 1363-1373.

ANDERSON AB. 1981. White-sand vegetation of Brazilian Amazonia. Biotropica 13: 199-210.

ARITA HT AND VÁZQUEZ-DOMIÍNGUEZ E. 2008. The tropics: cradle, museum or casino? A dynamic null model for latitudinal gradients of species diversity. Ecol Let 11: 653-660.

BORGES SH AND SILVA JMC. 2012. A new area of endemism for Amazonian birds in the Rio Negro basin. The Wilson J Ornithol 124: 15-23.

BOUBLI JP, RIBAS C, ALFARO JWL, ALFARO ME, SILVA MNF, PINHO GM AND FARIAS IP. 2015. Spatial and temporal patterns of diversification of the Amazon: a test of the riverine hypothesis for all diurnal primates of Rio Negro and Rio Branco in Brazil. Molec Phylogen Evol 82: 400-412.

CÁRDENAS D, GONZÁLEZ-CARO S, DUIVENVOORDEN J, FEELEY K AND DUQUE A. 2017. Asymmetrical niche determinismo across geological units shapes phylogenetic tree communites in the Colombian Amazonia. Persp Plant Ecolog Evol System 29: 1-9.

CARNEIRO-FILHO A, SCHWARTZ D, TATUMI SH AND ROSIQUE T. 2002. Amazonian paleodunes provide evidence for drier climate phases during the Late Pleistocene-Holocene. Quat Res 58: 205-209.

CORDEIRO CLO, ROSSETTI DF, GRIBEL R, TUOMISTO H, ZANI H, FERREIRA CAC AND COELHO L. 2016. Impact of sedimentary processes on white-sand vegetation in an Amazonian megafan. J Trop Ecol 32: 498-509.

CREMON ÉH, ROSSETTI DF, SAWAKUCHI AO AND COHEN MCL. 2016. The role of tectonics and climate in the late Quaternary evolution of a northern Amazonian River. Geomorphology 271: 22-39.

DAMASCO G, VICENTINI A, CASTILHO CV, PIMENTEL TP AND NASCIMENTO HEM. 2013. Disentangling the role of edaphic variability, flooding regime and topography of Amazonian white-sand vegetation. J Veget Sci 24: 384 394.

DICK CW, LEWIS S, MASLIN M AND BERMINGHAM E. 2013. Neogene origins and implied warmth tolerance of Amazon tree species. Ecol Evol 3: 162-169.

ELLERY WN, MCCARTHY TS AND SMITH ND. 2003. Vegetation, hydrology, and sedimentation patterns on the major distributary system of the Okavango fan, Botswana. Wetlands 23: 357-375.

FERNANDES AM, WINK M, SARDELLI CH AND ALEIXO A. 2014. Multiple speciation across the Andes and throughout Amazonia: The case of the spot-backed antbird species complex (Hylophylax naevius/Hylophylax naevioides). J Biogeogr 41: 1094-1104. 
FERREIRA M, FERNANDES AM, ALEIXO A, ANTONELLI A, OLSSON U, BATES JM, CRACRAFT J AND RIBAS CC. 2018. Evidence for mtDNA capture in the jacamar Galbula leucogastra/chalcothorax species-complex and insights on the evolution of white-sand ecosystems in the Amazon basin. Molec Phylogen Evol 129: 149-157.

FIELDING CR, ASHWORTH PJ, BEST JL, PROKOCKI EW AND SMITH GHS. 2012. Tributary, distributary and other fluvial patterns: What really represents the norm in the continental rock record? Sed Geol 261-262: 15-32.

FINE PVA AND BARALOTO C. 2016. Habitat endemism in white-sand forests: insights into the mechanism of lineage diversification and community assembly of the neotropical flora. Biotropica 48: 24-33.

FINE PVA, GARCIA-VILLACORTA RCA, PITMAN N, MESONES I AND KEMBEL SW. 2010. A floristic study of the white-sand forests of Peru. Ann Mo Bot Gard 97: 283-305.

FINE PVA AND KEMBEL SW. 2011. Phylogenetic community structure and phylogenetic turnover across space and edaphic gradients in western Amazonian tree communities. Ecography 34: 552-565.

FINE PVA, ZAPATA F AND DALY DC. 2014. Investigating processes of Neotropical rain forest tree diversification by examining the evolution and historical biogeography of the Protieae (Burseraceae). Evolution 68-7: 1988-2004.

FLORES BM, HOLMGREN M, XU C, VAN NES EH, JAKOVAC CC, MESQUITA RCG AND SCHEFFER M. 2017. Floodplains as an Achilles' heel of Amazonian forest resilience. Proc Nat Acad Sci United States Am 114: 44424446.

FRANCHITO SH, RAO VB AND FERNANDEZ JPR. 2012. Tropical land savannization: impact of global warming. Theoretic Applied Climatol 109: 73-79.

FRASIER CL, ALBERT VA AND STRUWE L. 2008. Amazonian lowland, white sand areas as ancestral regions for South American biodiversity: Biogeographic and phylogenetic patterns in Potalia (Angiospermae:Gentianaceae). Org Divers Evol 8: 44-57.

GARCÍA-VILLACORTA R, DEXTER K AND PENNINGTON RT. 2016. Amazonian white-sand forests show strong floristic links with surrounding oligotrophic habitats and the Guiana Shield. Biotropica 48: 47-57.

GARZON-ORDUNA IJ, BENETTI-LONGHINI JE AND BROWER AVZ. 2014. Timing the diversification of the Amazonian biota: butterfly divergences are consistent with Pleistocene refugia. J Biogeogr 41: 1631-1638.

GRIMALDI C AND PEDRO G. 1996. Importance de l'hydrolyse acide dans les systèmes pédologiques des régions tropicales humides. C R Acad Sci Paris 323: 483492.
GUEVARA JE ET AL. 2016. Low phylogenetic beta diversity and geographic neoendemism in Amazonian white-sand forests. Biotropica 48: 34-46.

GUMBRICHT T, MCCARTHY TS AND MERRY CL. 2001. The topography of the Okavango Delta, Botswana, and its tectonic and sedimentological implications. South African J Geol 104: 243-264.

HÄGGI C, CHIESSI CM, MERKEL U, MULITZA S, PRANGE M, SCHULZ M AND SCHEFUß E. 2017. Response of the Amazon rainforest to late Pleistocene climate variability. Earth Planet Sci Lett 479: 50-59.

HAMMOND DS AND TER STEEGE H. 1998. Propensity for fire in Guianan rainforests. Conserv Biol 12: 944-947.

HARTLEY AJ, WEISSMANN GS, NICHOLS GJ, SCUDERI LA, OLSON M, BUEHLER H AND BANTEAH R. 2010. Large distributive fluvial systems: characteristics, distribution, and controls on development. J Sed Res 80: 167-183.

HARVEY M, ALEIXO A, RIBAS CC AND BRUMFIELD RT. 2017. Habitat association predicts genetic diversity and population divergence in Amazonian birds. The Am Naturalist 190: 631-648.

HIGGINS MA, RUOKOLAINEN K, TUOMISTO H, LLERENA N, CARDENAS G, PHILLIPS OL, VÁSQUEZ R AND RÄSÄNEN M. 2011. Geological control of floristic composition in Amazonian forests. J Biogeogr 38: 2136-2149.

HOORN C, GUERRERO J, SARMIENTO GA AND LORENTE MA. 1995. Andean tectonics as a cause for changing drainage patterns in Miocene northern South America. Geology 23: 237-240.

KOENEN EJM, CLARKSON JJ, PENNINGTON TD AND CHATROU LW. 2015. Rencently evolved diversity and convergent radiations of rainforest mahoganies (Meliaceae) shed new light on the origins of rainforest hyperdiversity. New Phytol 207: 327-339.

LATRUBESSE EM AND FRANZINELLI E. 2005. The late Quaternary evolution of the Negro River, Amazon, Brazil: implications for island and floodplain formation in large anabranching tropical systems. Geomorphology 70: 372397.

LATRUBESSE EM AND NELSON BW. 2001. Evidence for Late Quaternary aeolian activity in the Roraima-Guyana Region. Catena 43: 63-80.

LEGENDRE P AND LEGENDRE L. 1998. Numerical Ecology. $2^{\text {nd }}$ ed., Amsterdam: Elsevier, 853 p.

MATOS MV, BORGES SH, D'HORTA FM, CORNELIUS C, LATRUBESSE E, COHN-HAFT M AND RIBAS CC. 2016. Comparative phylogeography of two bird species, Tachyphonus phoenicius (Thraupidae) and Polytmus theresiae (Trochilidae), specialized in Amazonian whitesand vegetation. Biotropica 48: 110-120. 
MENDONÇA BAF, SIMAS FNB, SHAEFER CEGR, FERNANDES-FILHOEI, VALE JR JF AND MENDONÇA JGF. 2014. Podzolized soils and paleoenvironmental impplications of white-sand vegetation (Campinarana) in the Viruá National Park, Brazil. Geoderma Reg 2-3: 9-20.

MILES LAAND GRAINGER PO. 2004. The impact of global climate change on tropical biodiversity in Amazonia. Glob Ecol Biogeogr 13: 553-565.

MISIEWICZ TM AND FINE PVA. 2014. Evidence for ecological divergence across a mosaic of soil types in an Amazonian tropical tree: Protium subserratum (Burseraceae). Molec Ecol 23: 2543-2558.

NAKA LN, BECHTOLDT CL, HENRIQUES LM AND BRUMFIELD RT. 2012. The role of physical barriers in the location of avian suture zones in the Guiana Shield, Northern Amazonia. The Am Natur 179: E115-E132.

NAKA LN, COHN-HAFT M, WHITTAKER A, BARNETT JM AND TORRES MF. 2007. Avian biogeography of Amazonian flooded forests in the Rio Branco Basin, Brazil. The Wilson J Ornithol 119: 439-449.

NICHOLS G AND FISHER J. 2007. Processes, facies and architecture of fluvial distributary systems deposits. Sed Geol 195: 75-90.

NOGUEIRA ACR, SILVEIRA R AND GUIMARÃES JT. 2013. Neogene Quaternary sedimentary and paleovegetation history of the eastern Solimões Basin, central Amazon region. J South Am Earth Sci 46: 89-99.

PATTON JL, SILVA MN AND MALCOLM JR. 2000. Mammals of the Rio Juruá and the evolutionary and ecological diversification of Amazonia. Am Mus Nat Hist Bull 244: 1-306.

PENNINGTON RT AND LAVIN M. 2016. The contrasting nature of woody plant species in different Neotropical forest biomes reflects difference in ecological stability. New Phytol 210: 25-37.

PESSENDA LCR, BOULET R, ARAVENA R, ROSOLEN V, GOUVEIA SEM, RIBEIRO AS AND LAMOTTE M. 2001. Origin and dynamics of soil organic matter and vegetation changes during the Holocene in a forestsavanna transition zone, Brazilian Amazon Region. The Holoc 11: 250-254.

PULLIAM HR. 1988. Surces, sinks, and population regulation. Am Nat 132: 652-661.

RADAMBRASIL 1976. Folha NA.20-Boa Vista Vista e parte das folha NA. 21-Tumucumaque, NB. 20 Roraima e NB. 21-Geologia, Geomorfologia, Pedologia, Vegetação e Uso Potencial da Terra. Dep Nac Prod Min, Rio de Janeiro, $428 \mathrm{p}$.

RÄSÄNEN M, SALO JS AND KALLIOLA RJ. 1987. Fluvial perturbance in the western Amazon basin: regulation by long-term sub-Andean tectonics. Science 238: 1398-1401.

RÄSÄNEN ME, SALO JS, JUNGNER H AND ROMEROPITTMAN L. 1990. Evolution of the Western Amazon lowland relief: impact of Andean foreland dynamics. Terra Nova 2: 320-332.

RIBAS CC, ALEIXO A, NOGUEIRA ACR, MIYAKI CY AND CRACAFT J. 2012. A paleobiogeographic model for biotic diversification within Amazonia over the past three million years. Proc R Soc B 279: 681-689.

RIBAS CC, MIYAKI CY AND CRACRAFT J. 2009. Phylogenetic relationships, diversification and biogeography in Neotropical Brotogeris parakeets. J Biogeogr 36: 1712-1729.

RODRIGUES WA. 1961. Aspectos Fitossociológicos das Caatingas do Rio Negro. Bol Mus Par. Emílio Goeldi, Botânica 15: 1-41.

ROSSETTI DF. 2014. The role of tectonics in the late Quaternary evolution of Brazil's Amazonian landascape. Earth-Science Rev 139: 362-389.

ROSSETTI DF, BERTANI TC, ZANI H, CREMON ÉH AND HAYAKAWA EH. 2012a. Late Quaternary sedimentary dynamics in Western Amazonia: implications for the origin of open vegetation/forest contrasts. Geomorphology 177: 74-92.

ROSSETTI DF, COHEN MCL, BERT ANI TC, HAYAKAWA EH, PAZ JDS, CASTRO DF AND FRIAES Y. 2014a. Late Quaternary fluvial terrace evolution in the main southern Amazonian tributary. Catena 116: 19-37.

ROSSETTI DF, GRIBEL R, RENNÓ CD, COHENM CL, MOULATLET GM, CORDEIRO CLO AND RODRIGUES ESF. 2017b. Late Holocene tectonic influence on hydrology and vegetation patterns in a northern Amazonina megafan. Catena 158: 121-130.

ROSSETTI DF, GRIBEL R, TUOMISTO H, CORDEIRO CLO AND TATUMI SH. 2018. The influence of late Quaternary sedimentation on vegetation in an Amazonian lowland megafan. Earth Surf Proc Landf 43: 1167-1369.

ROSSETTI DF, MOLINA EC AND CREMON EH. 2016. Genesis of the largest Amazonian wetland in northern Brazil inferred by morphology and gravity anomalies. J South Am Earth Sci 69: 1-10.

ROSSETTI DF, TOLEDO PM AND GÓES AM. 2005. New geological framework for Western Amazonia (Brazil) and implications for biogeography and evolution. Quat Res 63: 78-89.

ROSSETTI DF, VALERIANO MM, GRIBEL R, COHEN MCL, TATUMI SH AND YEE M. 2017a. The imprint of Late Holocene tectonic reactivation on a megafan landscape in the northern Amazonian wetlands. Geomorphology 295: 406-418.

ROSSETTI DF, ZANI H, COHEN MCL AND CREMON ÉH. 2012b. A Late Pleistocene-Holocene wetland megafan in Brazilian Amazonia. Sedim Geol 282: 276-293.

ROSSETTI DF, ZANI H AND CREMON ÉH. 2014b. Fossil megafans evidenced by remote sensing in the Amazonian wetlands. Z Geomorphol 58: 145-161. 
ROSSETTI DF ET AL. 2015. Mid-Late Pleistocene OSL chronology in western Amazonia and implications for the transcontinental Amazon pathway. Sedim Geol 330: 1-15.

RULL V. 2008. Speciation timing and neotropical biodiversity: the Tertiary-Quaternary debate in the light of molecular phylogenetic evidence. Mol Biol 17: 2722-2729.

RUOKOLAINEN K, TUOMISTO H, MACÍA MJ, HIGGINS MA AND YLI-HALLA M. 2007. Are floristic and edaphic patterns in Amazonian rain forests congruent for trees, pteridophytes and Melastomataceae? J Tropical Ecol 23: 13-25.

SOBERÓN J AND LLORENTE J. 1993. The use of species accumulation functions for the prediction of species richness. Conserv Biol 7: 480-488.

SOUSA-NEVES T, ALEIXO A AND SEQUEIRA F. 2013. Cryptic patterns of diversification of a widespread Amazonian Woodcreeper species complex (Aves: Dendrocolaptidae) inferred from multilocus phylogenetic analysis: Implications for historical biogeography and taxonomy. Molec Phylogen Evol 68: 410-424.

STANISTREET IG AND MCCARTHY T. 1993. The Okavango Fan and the classification of subaerial fan systems. Sed Geol 85: 115-133.

STROPP J, VAN DER SLEEN P, QUESADA CA AND TER STEEGE H. 2011. Seedling traits and herbivory in whitesand and terra-firme forests: an analysis across a resource gradient in the upper Rio Negro, In: Stropp J (Ed), Towards an understanding of tree diversity in Amazonian forests. PhD Thesis, Utrecht University, Utrecht.

TEEUW R AND RHODES E. 2004. Aeolian activity in northern Amazonia: optical dating of Late Pleistocene and Holocene palaeodunes. J Quat Sci 19: 49-54.

TER STEEGE H ET AL. 2006. Continental-scale patterns of canopy tree composition and function across Amazonia. Nature 443: 444-447.

TER STEEGE H ET AL. 2013. Hyperdominance in the Amazonian tree flora. Science 342: 1243092.

TER STEEGE H, JETTEN VG, POLAK AM AND WERGER MJA. 1993.Tropical rain forest types and soil factors in a Watershed area in Guyana. J Veg Sci 4: 705-716.
TER STEEGE H, SABATIER D, CASTELLANOS H, VAN ANDEL T, DUIVENVO-ORDEN J, OLIVEIRA AA, EK R, LILWAH R, MAAS P AND MORI S. 2000. An analysis of the floristic composition and diversity of Amazonian forests including those of the Guiana Shield. J Trop Ecol 16: $801-828$.

TUOMISTO H. 2007. Interpreting the biogeography of South America. J Biogeogr 34: 1294-1295.

TUOMisto H, MOULATLET GM, BALSLEV $\mathrm{H}$, EMILIO T, FIGUEIREDO FOG, PEDERSEN D AND RUOKOLAINEN K. 2016. A compositional turnover zone of biogeographical magnitude within lowland Amazonia. J Biogeogr 43: 2400-2411.

TUOMISTO H AND RUOKOLAINEN K. 1997. The role of ecological knowledge in explaining biogeography and biodiversity in Amazonia. Biodivers Conserv 6: 347-357.

TUOMISTO H, RUOKOLAINEN K AND YLI-HALLA M. 2003. Dispersal, environment, and floristic variation of Western Amazonian Forests. Science 299: 241-244.

VICENTINI A. 2004. A vegetação ao longo de um gradiente edáfico no Parque Nacional do Jaú. In: Borges SH et al. (Eds), Janelas para a biodiversidade no Parque Nacional do Jaú: uma estratégia para o estudo da biodiversidade na Amazônia, Manaus: Fundação Vitória Amazônica, WWFIBAMA, Amazonas, Brazil, p. 117-143.

VICENTINI A. 2016. The evolutionary history of Pagamea (Rubiaceae), a White-sand specialist lineage in tropical South America. Biotropica 48: 58-69.

ZANI H AND ROSSETTI DF. 2012. Multitemporal Landsat data applied for deciphering a megafan in northern Amazonia. Int J Remote Sens 33: 6060-6075.

ZULAR A, SAWAKUCHI AO, CHIESSI CM, D'HORTA FM, CRUZ FW, DEMATTÊ JAM, RIBAS CC, HARTMANN GA, GIANNINI PCF AND SOARES EAA. 2019. The role of abrupt climate change in the formation of an open vegetation enclave in northern Amazonia during the late Quaternary. Glob Planet Change 172: 140-149. 